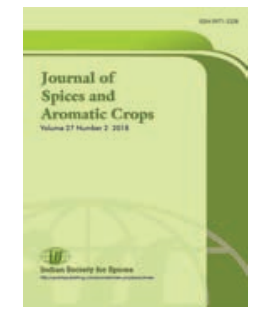

\title{
Root-knot nematode in garlic caused by Meloidogyne species: first record from Karnal district of Haryana state
}

\author{
R C Gupta* \& S Pandey \\ National Horticultural Research and Development Foundation, \\ Chitegaonphata, Nashik-422 003, Maharashtra. \\ *E-mail: rcg_9730@rediffmail.com
}

Received 25 June 2018; Revised 06 September 2018; Accepted 25 October 2018

\begin{abstract}
Garlic (Allium sativum L.) is an important spice crop cultivated all over the country during Rabi season except in Ooty hills of Tamil Nadu where it is grown during rainy season. Garlic suffers from various fungal, bacterial as well as viral diseases causing severe yield loss in different cultivated areas in the country. During a survey in garlic fields at village Muradgarh, Tahsil-Indri of Karnal district of Haryana in November, 2016, a number of small, medium and big root galls mostly formed in root tips were observed in six week old garlic plants on local cultivar-Sankar. The infestation of root-knot nematode in garlic was severe and noticed in patches in the field. To the best of our knowledge, this is the first report of root-knot nematode affecting garlic from Karnal district of Haryana.
\end{abstract}

Keywords: garlic, Meloidogyne species, root-knot nematode

Garlic (Allium sativum L.) is an important spice crop cultivated all over the country during Rabi season except in Ooty hills of Tamil Nadu where it is grown during rainy season. Garlic is used as spice and also for medicinal purposes in different ways. India is the second largest producer of garlic after China (Garg \& Sekhon 2016). Haryana, Madhya Pradesh, Gujarat, Rajasthan and Tamil Nadu are the major garlic growing states producing more than $80 \%$ of garlic in the country. However, the productivity is quite low due to biotic stresses mainly caused by fungi and viruses. During a survey in garlic fields at village Muradgarh in Karnal district of Haryana in the month of November, 2016, garlic plants with yellowing and tip drying, the true to type symptoms of root-knot nematode, Meloidogyne species was observed (Fig. 1). Affected garlic plants were uprooted and found numerous typical root galls known as root-knot disease (Fig. 3). A number of small, medium and big root galls were observed on infected garlic plants which ranged from 3 to 12 root galls/plant in six week old infected garlic crop on common local cultivar-Sankar (Fig. 2). The root galls were oval, round and cylindrical in shape and the average size was $0.76 \times 1.80 \mathrm{~cm}$. The nematode galls are mostly formed in root tips of garlic plant. The infestation of root-knot nematode in garlic was severe and noticed in patches of the field. The farmers cultivate garlic followed by paddy in Indri area of Karnal district in Haryana and 


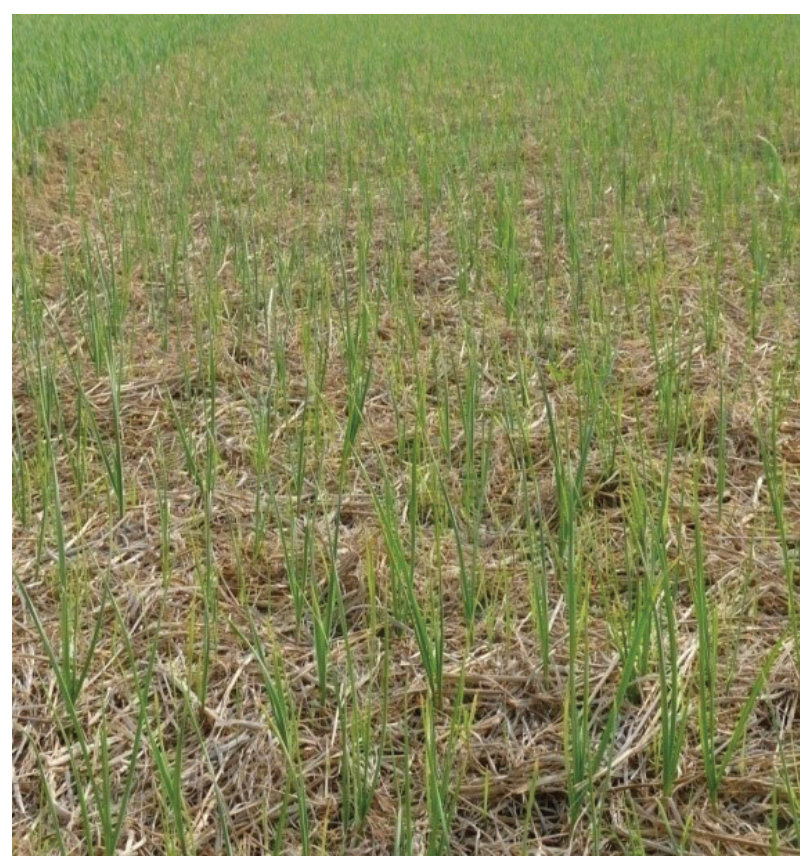

Fig. 1. Root-knot nematode affected field of garlic

paddy straw is used for mulching in garlic crop. The population of second stage juveniles of Meloidogyne species was obtained from eggs. The pathogenicity of the root-knot nematode was established in pot culture. The eggs were obtained by blending galled root segments in $1.0 \%$ sodium hypochlorite solution for 3 minutes and rinsed several times with tap water and further allowed to hatch in tap water for 48 hours. Juveniles were picked randomly, placed in a drop of water on a glass slide, killed by gentle heat and covered with the cover slip for measurement (Pokharel et al. 2007). The morphometrical characters of egg, $2^{\text {nd }}$ stage juveniles (J2), male and female of root-knot nematode were observed under light binocular microscope (Olympus U-CMAD3). The average size of egg $(90.30 \times 38.20 \mu \mathrm{m}), 2^{\text {nd }}$ stage juvenile $(440 \times 16.70 \mu \mathrm{m})$, male $(1220 \times 32.10 \mu \mathrm{m})$ and female $(535 \times 380 \mu \mathrm{m})$ were measured respectively. The mature female was picked from galled roots of garlic and placed on a glass slide in a drop of water for perineal pattern study. The posterior end was cut with a sharp razor blade and cleaned the glass slide with the female end (cut side down) was covered with a cover slip and sealed. The perineal pattern was examined under a compound microscope. The perineal pattern of the female was dorso-ventral, oval almost circular in shape, moderate arc height, it was further

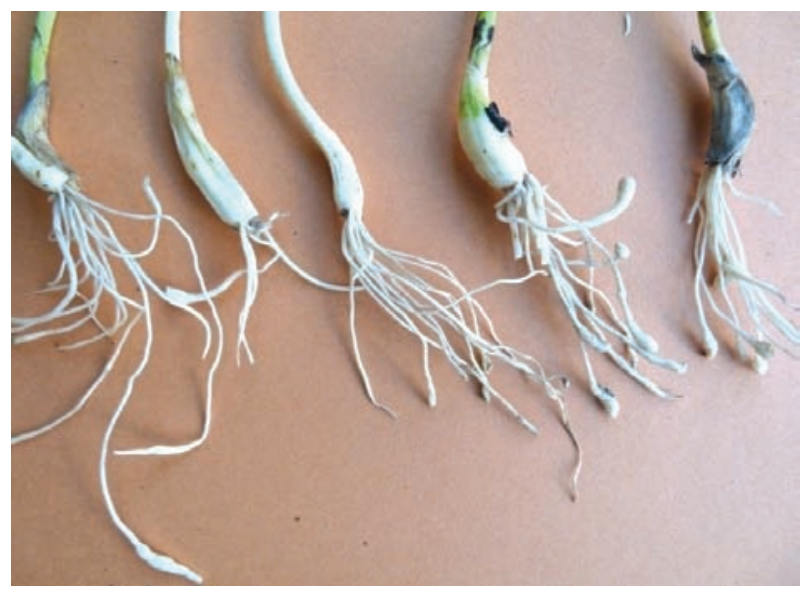

Fig. 2. Small to large root-knot nematode galls at the root tips of garlic

noted that, no lateral incisures of gaps were observed. The tail tip marked with prominent coarse and fairly separated striae was also observed. These perineal pattern was similar to the pattern described for Meloidogyne graminicola with some minor variations (Handoo et al. 2003; Pokharel et al. 2007). A comparison of the morphometrical characteristics in the descriptions of Meloidogyne graminicola by Golden and Birchfield (1965) and subsequently by Mulk (1976). The population of root-knot nematode is maintained in garlic under pot culture for species level characterization and further studies.

Gergon et al. (2002) reported that, the rice rootknot nematode (Meloidogyne graminicola) infect all commercially grown onion cultivars in riceonion cropping system in Phillippines. Further,

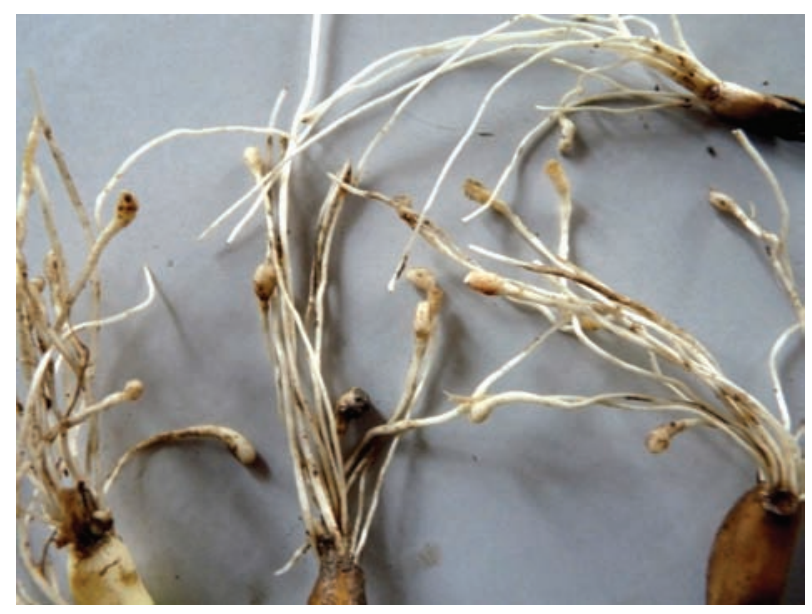

Fig. 3. Close-up of root-knot nematode (Meloidogyne species) galls at the root tips of garlic 
the root-knot nematode, Meloidogyne graminicola on onion was first time reported in India from Karnal area of Haryana state and the morphological characters were similar to the observations of Mishra et al. (2010). Recently, Mohamed (2015) conducted an extensive survey of major garlic cultivated areas to determine the abundance of plant parasitic nematodes associated with garlic in Yemen. He recorded 20 genera of plant parasitic nematodes associated with garlic including Meloidogyne species causing root-knot disease. Some workers have reported that, root-knot nematodes (Meloidogyne species) are parasitic to broad range of vegetables and fruit crops and causing considerable economic yield losses (Anwar et al. 2007: Bourne et al. 2004; Maru et al. 2013; Singh 2012; Singh et al. 2014). The root-knot nematode, Meloidogyne javanica on strawberry was first time reported in India from Jammu by Singh (2012).

Ravindra et al. (2015) first time reported the rootknot nematode in garlic caused by Meloidogyne species from Karnataka in India. To the best of our knowledge, this is the first report of rootknot nematode affecting garlic from Karnal district of Haryana. Therefore, there is need for taking appropriate measures in the infected area not only to arrest the further spread of nematodes but also to sanitize the fields.

\section{References}

Anwar S A, Zia A, Hussain M \& Kamran M 2007 Host suitability of selected plants to Meloidogyne incognita in the Punjab, Pakistan Int. J. Nematol. 17: 144-150.

Bourne J M, Karanja P K, Kalisz H, Karanja D K, Mauchline T H \& Kerry B R 2004 Incidence and severity of damage caused by Meloidogyne spp. and isolation and screening of the nematophagous fungus Pochonia chlamydosporia from some of the main vegetable growing areas in Kenya. Int. J. Nematol. 14: 111-120.

Garg N \& Sekhon K S 2016 Earliness, yield and bulb parameters of hardneck garlic (Allium sativum L.) as influenced by leaf knotting and scape removal in north Indian plains. J. Spices Arom. Crops 25: 182-186.
Gergon E B, Millar S A, Halbrendt J M \& Devide R G 2002 Effect of rice root knot nematode on growth and yield of yellow Granex onion. Plant Dis. 86: 1339-1344.

Golden A M \& Birchfield W 1965 Meloidogyne graminicola (Heteroderidae) a new species of root-knot nematode from grass. Proceedings of the helminthological Society of Washington 32: 228-231.

Handoo Z A, Klassen W, Abdul-Baki A, Bryan H H \& Wang Q 2003 First record of rice root-knot nematode (Meloidogyne graminicola) in Florida. J. Nematol. 35: 342.

Maru A K, Sddiqui A U, Parihar A, Sharma S K \& Srivastava A S 2013 Effect of different formulations of entomopathogenic nematode Steinernema carpocapsae against root knot nematode Meloidogyne incognita on tomato. Indian Phytopath. 66: 413-415.

Mishra R K, Singh S, Pandey S, Sharma P \& Gupta R P 2010 First report of root knot nematode Meloidogyne graminicola in onion in India. Int. J. Nematol. 20: 236-237.

Mohamed R M 2015 Plant parasitic nematodes associated with garlic in Yaman. Ezypt J. Agronematol. 14: 37-44.

Mulk M M 1976 Meloidogyne graminicola C.I.H. description of plant parasitic nematodes, set 6, No.87 UK: Commonwealth Agricultural Bureau.

Pokharel R R, Abawi G S, Zhang N, Duxbury J M \& Smart C D 2007 Characterization of isolates of Meloidogyne from rice-wheat production fields in Nepal. J. Nematol. 39: 221-230.

Ravindra H, Sahgal Mukesh, Narasimhamurthy H B \& Saumya D M 2015 First report of root knot nematode (Meloidogyne spp.) on garlic in India. Indian J. Nematol. 45: 121-122.

Singh N, Maheshwari M N, Chaudhari S M \& Patel D J 2014 Integrated management of (Meloidogyne incognita) in potato. Indian Phytopath. 67: 418-422.

Singh V K 2012 Meloidogyne javanica of strawberrya new host record from India. Indian Phytopath. 65: 211. 